\title{
Revisiting the Norse on the Western Isles from a Landscape Perspective
}

\begin{abstract}
Historically the research on the relationship between the Norse and Pictish period population of the Western Isles has largely focused on place-name evidence, due to the prevalence of Old Norse place names over Pictish period ones and a scant archaeological record. Placename scholars, as well as archaeologists have traditionally split into two schools of interpretation: a 'war school' and a 'peace school'. The war school argues that the archaeological and place-name material contains proof of a Norse genocide against the Pictish period inhabitants, while the peace school has advocated assimilation or acculturation. In the last few decades excavations and surveys have given a better understanding of the Norse presence on the islands. This article approaches the question of whether the Pictish period population survived, through an archaeological landscape analysis that incorporates settlement sites and uses place-name data. It argues that the landscape displays proof of a surviving Pictish period culture within a dominant Norse society, though this survival was probably asymmetrical and regional.
\end{abstract}

\section{Introduction}

Debates on ethnicity have been at the forefront of research regarding the Norse period (AD 800-1250) ${ }^{1}$ of the Western Isles, also called the Outer Hebrides, (Old Norse [ON]: Suðreyjar) of Scotland for the last few decades. Archaeological evidence and place names have been used in arguments that either suggest that the Pictish period population (AD 200-800) ${ }^{2}$ were assimilated, acculturated, or subjected to a genocide, by the Norse ${ }^{3}$, who first appeared in the islands around AD 800 (Smith 2001; Jennings and Kruse 2005). New archaeological evidence and surveys have allowed for a revitalisation of the debate on the nature of the demographic change that occurred in the Norse Period.

The intention of this article is to better understand the Norse attitude towards the past and their view of the encounter with the Pictish population of the islands. This will be done by attempting to answer the following questions: what can the landscape tell us about the Norse settlement of the Western Isles? What can the reuse of Pictish period settlements tell us

Contact: Joseph Thomas Ryder, E-mail: joseph.ryder@uib.no

1 Department of Archaeology, History, Culture History and Religious Studies, University of Bergen 


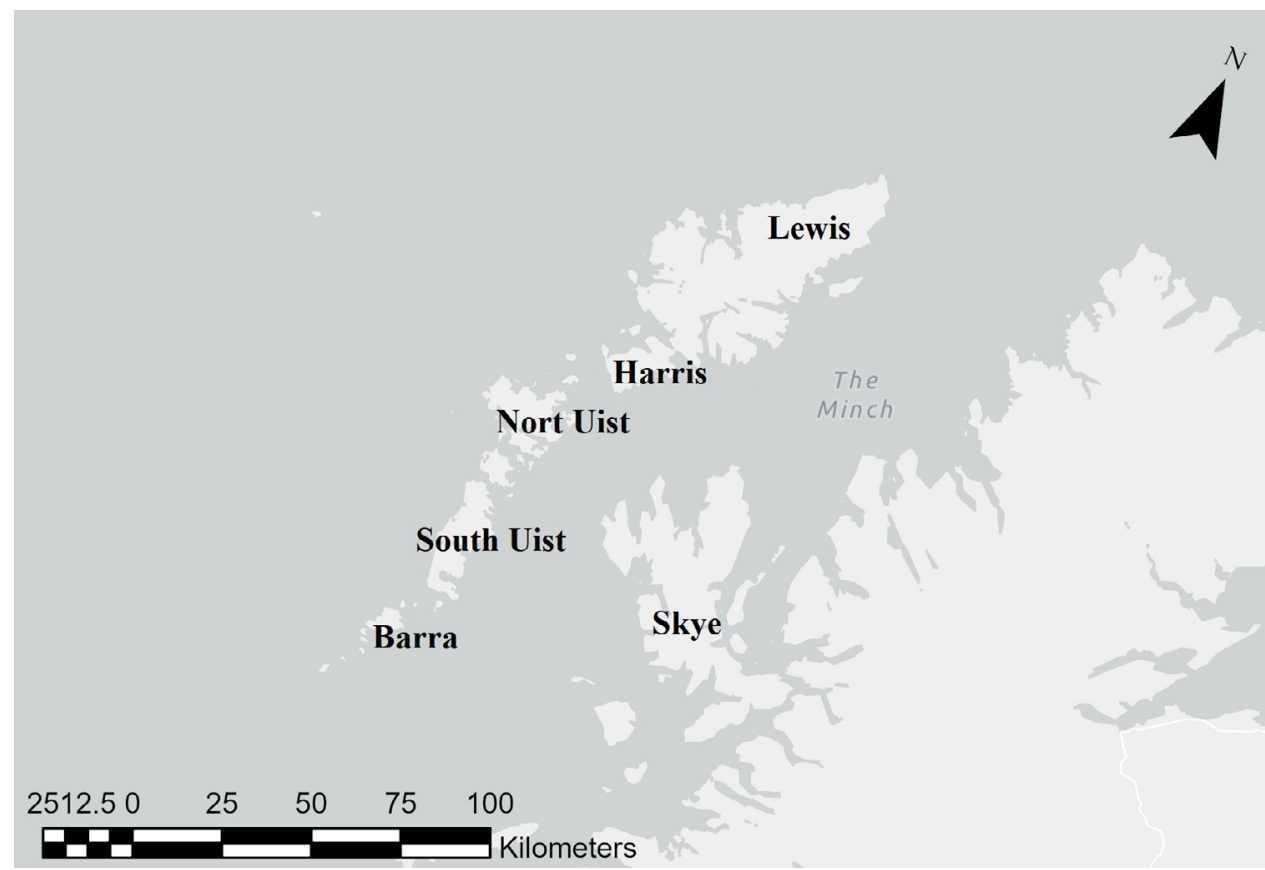

Figure 1. Skye and the Western Isles, with names of the major islands and places in the area of study.

about the relationship between the Norse and the existing population? The article investigates the archaeological, geographical and topographical contexts of the settlement sites of the Norse to explore their attitude towards the Pictish period population and their settlements. The methodology incorporates landscape and topographical analyses of each site, as well as place-name evidence.

\section{Background: The Norse and the Picts in the Western Isles}

Archaeological, historical, and toponymical data provide evidence of an influx of Norsespeaking and cultured people in the Western Isles during the $9^{\text {th }}$ century (Armit 1996: 1868). Peoples who can be described as Pictish cultured populated the Western Isles at the onset of the Viking Age. Within the Norse North Atlantic region, cultural signifiers, such as longhouses, steatite vessels, and furnished burials appear in archaeological records from the $9^{\text {th }}$ century. Moreover, an abrupt decline in Pictish period culture is observable through the abandonment of settlements in the late $8^{\text {th }}$ and early $9^{\text {th }}$ centuries (Armit 1996: 186). The amount of linguistic data is also significant and in the Western Isles Old Norse (ON) place names predate the Gaelic ones, suggesting a large-scale and long-term Norse colonisation (Crawford 1987; Armit 1996; Graham-Campbell and Batey 1998).

Within Norse studies of Northern and Western Scotland, two schools of thought attempt to explain the process of demographic change: the 'peace school' and the 'war school' (Barrett 2003). In sum, one side argues genocide, mostly due to Old Norse place-names 
replacing Pictish period ones (Smith 2001) and through archaeological evidence, e.g. the Norse longhouse built over a Pictish period elite settlement at the Udal, on North Uist, which has been interpreted as an indicator of ethnic cleansing by previous researchers (Crawford 1981; Crawford 1987: 140; Jennings and Kruse 2005). Other scholars argue for processes of assimilation, acculturation, or hybridisation (Ritchie 1993; Sharples and Parker Pearson 1999). The widespread Norse pottery style which developed in the Hebrides during the Norse period, suggests the survival of Pictish potters and pottery traditions, since western Norway was largely aceramic at the time (Lane 2012:215). Based on this same evidence Niall Sharples and others have also argued that a small, yet culturally distinct, indigenous population survived (Sharples et al. 2015; Sharples 2019). Ian Armit has suggested that the abandonment of monumental Pictish structures during the Norse period indicates that the Pictish period elite was replaced by a Norse one (Armit 1996). Agreeing with Armit, Mary MacLeod Rivett (2016: 157) and John Raven (2005: 137) have also argued for an intentional abandonment of monumental Pictish structures during the Viking Age, followed by a symbolic readaptation resulting from the growing Gaelic influx in the Late Norse period (1050-1250). DNA evidence has also been used to explain ethnicity in the Hebrides and the rest of Norse Scotland. Recent research has shown that two bodies from a pagan Norse burial in Orkney, were in fact of Pictish or indigenous descent (Margaryan, Lawson, Sikora et al. 2020). It must be said, however, that it is difficult to apply DNA data to this area. Modern Hebrideans have just c. 7\% West-Norwegian DNA, compared to c. $23 \%$ for Orcadians (Gilbert, O’Reilly, Merrigan et al. 2019). Earlier DNA studies have highlighted that the Hebrides have a much higher ratio of male than female West-Norwegian DNA, in contrast to Orkney and Shetland, that have roughly 50\% of each (Goodacre, Helgason, Nicholson et al. 2005). This has been interpreted as the Hebrides being more of a 'frontier' where Norse men intermarried with locals to a higher extent (ibid).

The Norse colonisation of the Western Isles introduced a new form of architecture to the Hebrides, the Norse longhouse. Excavations of longhouses in the Western Isles reveal that the longhouse tradition there continued after the Viking Age, into the $13^{\text {th }}-15^{\text {th }}$ centuries (Cowie \& Rivett 2015; Parker Pearson 2018; Sharples 2019). This is also the case for Norse Orkney and Shetland, where Norse longhouses are known to have existed at the same time as churches, such as at Orphir, on the Orkney mainland. The continued Northern isles' longhouse tradition after AD 1000 has been interpreted as a regional identity, separate from the Scandinavian one (Barrett 2015: 4; Griffiths 2015: 232). A similar identity for the Hebrides has been proposed by Judith Jesch based on the distribution of Norse Hebridean pottery (Jesch 2015: 60-1). Also visible in Western Isles' excavations, is the continued maintenance, construction and function of Norse longhouses after AD 1000, which strengthens the idea of a regional Hebridean identity. There are some features that can be used to identify a Norse longhouse, though in the Viking Age it is difficult to define a 'typical' one, both in terms of style and function (Sauvage \& Mokkelbost 2016: 289). Viking Age building traditions differ regionally (Gjerpe 2016). In general, the Norse longhouse can be defined as being at least twice as long as it is wide, roughly rectangular to sub-rectangular in shape, ranging from small or modest-sized farmsteads to so called drinking halls, up to $80 \mathrm{~m}$ long (e.g. Croix 2014). In the Viking Age, particularly the larger Norse longhouses were magnate farmsteads, serving as centres for agricultural and industrial production, as well as social, religious and political activity (Dommasnes, Gutsmiedl-Schümann and Hommedal 2016: 145). 
Although it is difficult to define a 'typical' Norse settlement site, some patterns are distinguishable. In Norway, houses tended to be located centrally and infield (Øye 2009: 45), whereas in the Faroes and Shetland Norse farmsteads were placed on flat areas of arable land near landing places for boats (Small 1969). The work of Jane Harrison indicates that in Orkney Norse settlements tended to be located in direct relationship to earlier Pictish period ones, focused around settlement mounds, but also here on fertile land, near natural sheltered harbours (2013). From a practical perspective, the placement displays the Norse need for farmland and landing places. However, mounds could also be tools for political legitimisation, symbolising Norse cultural dominance (Griffiths and Harrison 2011) and at same time functioning as physical expressions of landownership (Zachrisson 1994; Gansum 1995; Skre 1998; Iversen 2008). The political, cultic, and territorial Viking Age usage of mounds in Scandinavia has been established in scholarship, e.g. at Hove, in Sognefjord (Dommasnes, Gutsmiedl-Schümann \& Hommedal 2016: 145). In my area of study, it has been suggested that the clusters of settlement mounds at Bornais on South Uist indicate a centre for political administration (Parker Pearson 2012).

Before the arrival of the Norse the inhabitants of the northern Hebrides largely belonged to the Pictish, Celtic-speaking culture, although other influences may have been present as well. This can be seen in the presence of Pictish symbol stones, e.g. on nearby Skye (Armit 1996: 160). Square shaped Pictish burial cairns have also been excavated and surveyed in the region (Parker Pearson 2018). Pictish architecture is characterised by drystone-built roundhouses, so called figure-8 or 'jelly baby' houses (Armit 1996: 169). Such houses are often found in areas of Norse settlement, e.g. at Bostadh, on Lewis (Neighbour and Burgess 1997), at the Udal, on North Uist (Crawford 1981), and at Bornais, on South Uist (Sharples 2005). These houses have semi-subterranean floors about 1-2 m deep, with single-skinned drystone walls.

The Viking Age in the region coincides with the end of these indigenous architectural traditions and the introduction of Norse longhouse traditions. However, Niall Sharples and Mike Parker Pearson have argued for a hybrid tradition called the Hebridean Longhouse, based on excavated longhouses on South Uist (1999). The presence of single-skinned drystone walled, semi-subterranean longhouses at Late Norse settlements on South Uist: i.e. at Bornais, Cille Pheadair and Drimore, may be seen as a combination of native and Norse architecture. Sharples and Parker Pearson have argued that the Hebridean longhouse is evidence of a Pictish-Norse continuity (ibid). This has been disputed since features such as single-skinned walls or subterranean floors were also found in contemporary Norwegian architecture (Jennings and Kruse 2005). However, there are major issues with Jennings and Kruse's argument since in Norway subterranean features are only found in so called pithouses, while there are no such features, or single-skinned walls in West-Norwegian longhouse building traditions (Søren Diinhoff, personal communication 2020). Additionally, in recent years, Sharples has argued that the earliest Norse settlement in the area of study was built of turf and timber, which supports the theory that Pictish period building traditions were abandoned (Sharples 2019). Altogether, this suggests two breaks in building traditions: an initial end to pre-Norse architectural styles and a later hybridisation of the Norse longhouse in the mid to late $10^{\text {th }}$ century. Moreover, according to Sharples, the single-skinned and semi-subterranean changes to the Norse longhouse architectural style would not have been without cultural meaning (Sharples et al. 2015). 


\section{Methodology and Materials}

I have used a research plan focusing on landscape analysis to help me contextualise the Norse settlement sites; to determine the nature of Norse settlements and their relationship to the Pictish period past; and to explore the Norse attitude towards the Pictish period population on the Western Isles. The approach is similar to studies on the Norse reuse of Pictish period settlement mounds in Orkney by Jane Harrison (2013) and Norse-era settlement mounds (Norwegian: gårdshauger) identified in northern Norway (Bertelsen 1973; Martens 2016). In the study area the Norse settlements were identified through the presence of Norse period pottery near key landscape features on agricultural land, such as settlement mounds or middens. Only sites with known provenance and identifiable Norse material culture were used. In addition, this article emphasises topographical relationships, especially between maritime ones, e.g. harbours and the Norse settlements. My intention was to explore Norse attitudes toward the Pictish period descendants through the placement of settlements in the landscape and a detailed and systemic investigation of the material culture.

Two of the Western Isles were chosen for a comparative case study: South Uist and Lewis. These islands are comparable since both have many settlement mounds identified as Norse through surveys and artefact recovery. South Uist has, however, been far more comprehensively excavated and researched due to the systemic surveys of its western machair coastline conducted in the 1990s by the SEARCH project from Cardiff University (Parker Pearson 2012).

The Norse settlement sites that displayed archaeological material were placed in their landscape context, including relationships to arable land, lochs, harbours and sea-routes. The sites were also compared spatially to earlier Pictish period settlement sites. These spatial relationships are displayed in tables. Further analysis was made through Geographical Information Systems (GIS) maps.

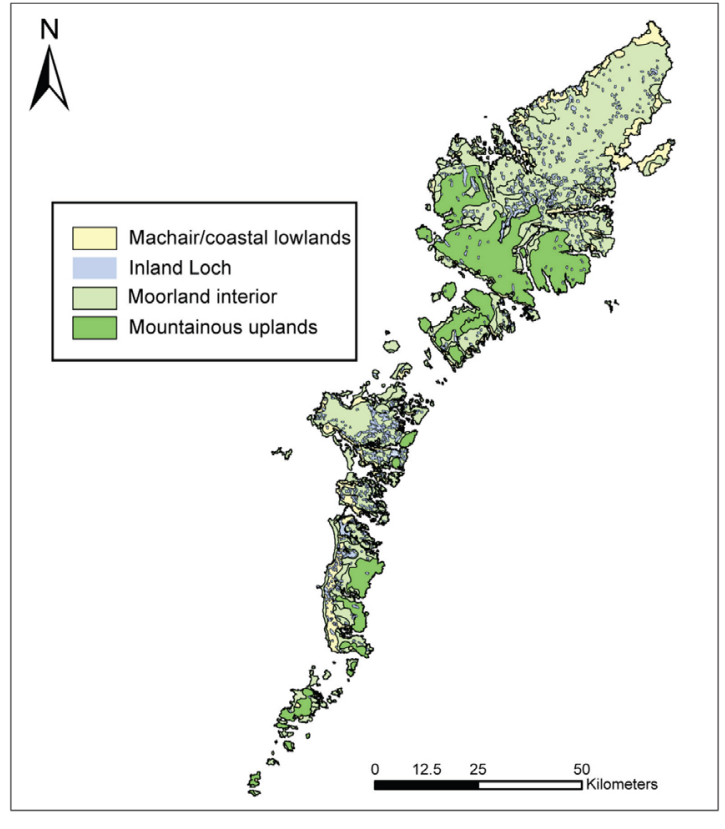

Figure 2. Map of the machair in Scotland. After Rennell 2015, page 22, figure 5. 
Reuse of settlement sites was determined through these criteria: i) Imposition, the Norse site is directly on top of an existing Iron Age or Pictish period settlement site, ii) Within 200-500 m, the Norse site is within a 200-500 m radius of an Iron Age or Pictish period settlement site.

Excavations and surveys on the west coast of South Uist have given researchers an excellent opportunity to study Norse settlement landscapes (Parker Pearson 2018). Over 20 Norse settlement mounds have been discovered on the machair (Fig. 2\&3). These mounds represent centuries of cultural deposits, some from earlier prehistory, such as the Bronze Age, and others possessing post-Norse medieval and modern layers (ibid). These mounds range in size, with the smallest measuring c. $5 \mathrm{~m}$ and the largest ones c. $100 \mathrm{~m}$ in diameter (Parker Pearson 2012). The machair is a landscape type featuring grass-covered sand plains found in north-western Scotland and Ireland, which was exploited by the Norse (ibid). The machair is fertile though fragile and in need of careful management (Parker Pearson 2012). Although this landscape type is unusual in Scandinavia (a similar landscape to the machair is found in Northern Norway, particularly Lofoten and Vesterålen, where the nucleus for settlement mounds is in the area), the Norse seem to have used and favoured the machair plains, not only on South Uist, but elsewhere in the region as well (Ryder forthcoming).

The best way to study various aspects of Norse society on the Western Isles would be through an extensive study of the Norse archaeological record from the area, which unfortunately is very limited both in quality and quantity (summarised by Sharples 2019). There have only been two extensively excavated and published sites: Bornais and Cille Pheadair on the west coast of South Uist.

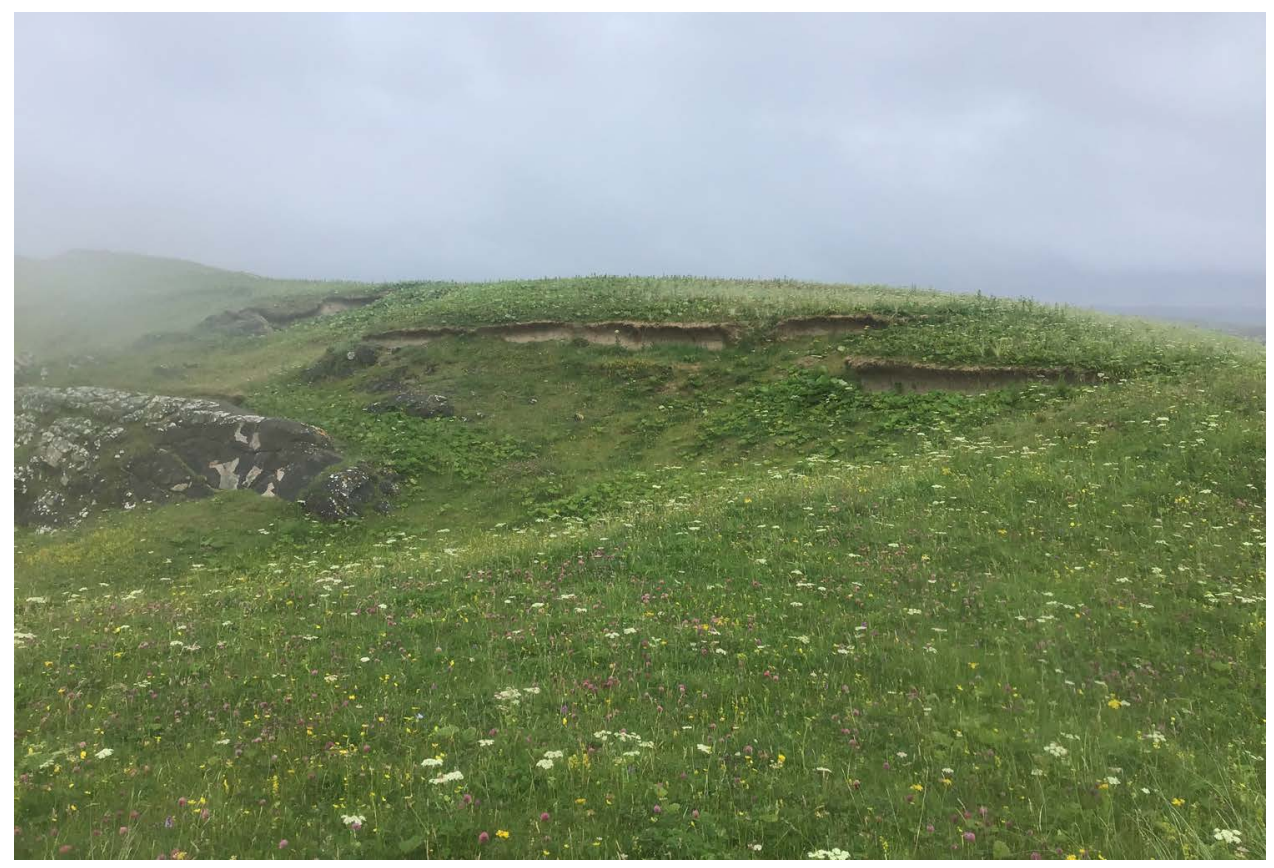

Figure 3. Machair plain at Cnip, Lewis. Photo: Joseph Thomas Ryder. 
Bornais was a Norse settlement from the late $9^{\text {th }}-14^{\text {th }}$ centuries (Sharples 2019: 94 ). Mound 1 is the earliest, where House 1 , dating from the beginning of the $10^{\text {th }}$ century, was built on top of a Pictish period settlement. Parker Pearson and Sharples have suggested that Bornais was a power centre for South Uist and possibly even for all of the Hebrides due the size of its longhouses and assemblage (Parker Pearson 2012; 2018; Sharples 2019). The archaeological remains at Bornais indicate that there was a gap in its settlement, i.e. from the last Pictish activity to the earliest Norse occupation, which could range anywhere between 15 and 230 years (Sharples 2019: 95). Although the first longhouse was built entirely of timber and turf, subsequent longhouses were all stone-built Hebridean styled ones. Sharples has interpreted the site data as suggesting an initial displacement of the Pictish population, however, with a significant minority surviving, which is reflected in the development of the Hebridean longhouse, pottery traditions, and the continuation of weaving traditions (Sharples forthcoming).

The Norse settlement at Cille Pheadair dates from the $10^{\text {th }}-13^{\text {th }}$ centuries (Parker Pearson 2018). Both the size and assemblage of the site indicate a modest farmstead. The longhouses at Cille Pheadair were Hebridean styled semi-subterranean and built with single-skinned stone foundations. There were no traces of earlier settlements nearby, although, due to the fragile coastline, it is possible that an earlier site may have been destroyed before any scientific surveys were conducted (Parker Pearson 2018).

A few sites on Lewis have undergone limited excavations. The first, at Barvas, has a Norse settlement dated to the $10^{\text {th }}-13^{\text {th }}$ centuries (Macleod Rivett 2016: 154). Barvas has been compared to Cille Pheadair, both in function and landscape (Cowie and Macleod Rivett 2015) and does not appear to have been built over a predecessor. The second, Bostadh (ON: bólstaðr: habitation, farm), occupies a north-facing beach on the island of Great Bernera, off the west coast of Lewis, and reveals a complex, multi-period settlement site that is currently mostly unpublished (Neighbour and Burgess 1997). This undated Norse site was partially built from remains of a Pictish figure-8 house (ibid: 113-4). The Norse structural remains were fragmentary but Michael Church has suggested that most of the building was made of turf and timber (Church 2002: 65).

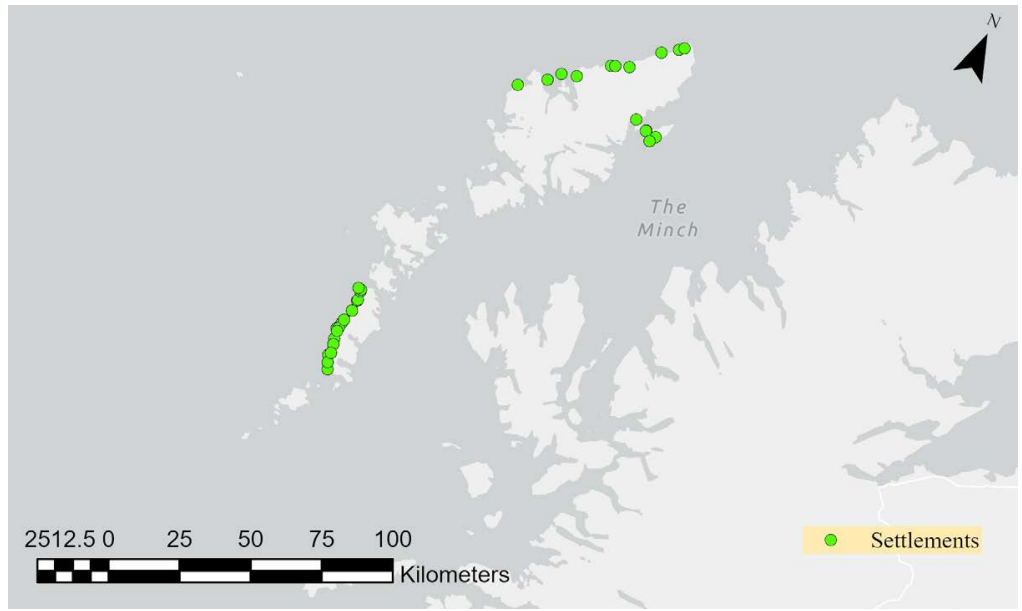

Figure 4. Norse settlement sites on Lewis and South Uist. 


\section{Results}

The study has identified 39 Norse settlement sites within the study area as detailed in tables $1 \& 2$. Approximately $54 \%$ of these sites can be said to be either overlaying or within a 200 to $500 \mathrm{~m}$ radius of a Pictish period/Iron Age settlement. This suggests that more than half of all Norse settlement sites are spatially related to Pictish period or Iron Age settlement sites, indicating an intentional Norse reuse of the settlement landscape. A comparison between South Uist (Table 1) and Lewis (Table 2) contains both similarities and differences. According to Mike Parker Pearson's machair survey (2012) on South Uist (Fig. 5) c. 26 Norse settlement mounds were identified through Norse pottery scatters. On Lewis (Fig. 6) 13 settlement sites were identified (the low number can probably be attributed to the lack of systematic survey conducted on the island).

\begin{tabular}{|c|c|c|c|c|c|}
\hline South Uist & $\begin{array}{l}\text { Distance to } \\
\text { harbour (metres) }\end{array}$ & $\begin{array}{l}\text { Nearest Loch } \\
\text { (metres) }\end{array}$ & Landscape & Reuse & $\begin{array}{l}\text { Type of } \\
\text { re-use }\end{array}$ \\
\hline Bornais Mound 1-3 & 1400 & 200 & Machair & Pictish & Overlain \\
\hline Ormacleit & 2000 & 1000 & Machair & Pictish & Adjacent \\
\hline South Bornais & 300 & 450 & Machair & Pictish & Adjacent \\
\hline Staoinebrig 1-2 & n/a & 200 & Machair & $n / a$ & $\mathrm{n} / \mathrm{a}$ \\
\hline Frobost 1-2 & n/a & 350 & Machair & Pictish & Overlain \\
\hline Baghasdal & $\mathrm{n} / \mathrm{a}$ & 700 & Machair & Pictish & Overlain \\
\hline Aisgernis & $\mathrm{n} / \mathrm{a}$ & 500 & Machair & $\mathrm{n} / \mathrm{a}$ & n/a \\
\hline Dalabrog 1 & 500 & 1200 & Machair & $\mathrm{n} / \mathrm{a}$ & $\mathrm{n} / \mathrm{a}$ \\
\hline Dalabrog 2 & 300 & 1500 & Machair & $\mid A$ & Adjacent \\
\hline Cille Pheadair & n/a & 1500 & Machair & $\mathrm{n} / \mathrm{a}$ & $\mathrm{n} / \mathrm{a}$ \\
\hline Smercleit & 600 & 600 & Machair & $\mathrm{n} / \mathrm{a}$ & n/a \\
\hline Cille Donnain 1 & n/a & 200 & Machair & $\mathrm{n} / \mathrm{a}$ & n/a \\
\hline Cille Donnain 2 & n/a & 300 & Machair & n/a & $\mathrm{n} / \mathrm{a}$ \\
\hline Dreumasadal & n/a & 700 & Machair & Pictish & Adjacent \\
\hline Drimore & n/a & 1500 & Machair & Pictish & Adjacent \\
\hline Gearraidhfleug & n/a & 1300 & Machair & Pictish & Overlain \\
\hline $\begin{array}{l}\text { Machair Mheadhanach / } \\
\text { lochdar } 1\end{array}$ & n/a & 2000 & Machair & Pictish & Overlain \\
\hline $\begin{array}{l}\text { Machair Mheadhanach } \\
2-4\end{array}$ & n/a & 700 & Machair & $\mathrm{n} / \mathrm{a}$ & n/a \\
\hline $\begin{array}{l}\text { Machair Mheadhanach/ } \\
\text { lochdar } 2\end{array}$ & n/a & 700 & Machair & Pictish & Overlain \\
\hline
\end{tabular}

Table 1. Settlement sites on South Uist. 


\begin{tabular}{|l|l|l|l|l|l|}
\hline Lewis & $\begin{array}{l}\text { Distance to } \\
\text { harbour (metres) }\end{array}$ & $\begin{array}{l}\text { Nearest Loch } \\
\text { (metres) }\end{array}$ & Landscape & Re-use & $\begin{array}{l}\text { Type of } \\
\text { re-use }\end{array}$ \\
\hline Mangersta & 150 & 500 & Machair & IA & Overlain \\
\hline Swainbost & 150 & $\mathrm{n} / \mathrm{a}$ & Machair & Unknown & Unknown \\
\hline Galson & 50 & $\mathrm{n} / \mathrm{a}$ & Machair & IA & Overlain \\
\hline Dun Eistean & 50 & $\mathrm{n} / \mathrm{a}$ & Machair & IA & Within \\
\hline Barvas & 800 & 1000 & Machair & IA & Within \\
\hline Arnol & 50 & 200 & Machair & IA & Overlain \\
\hline Bragar & 50 & 200 & Machair & IA & Within \\
\hline Bostadh & 50 & 700 & Machair & Pictish & Overlain \\
\hline Cnip settlement & 50 & 500 & Machair & IA & Within \\
\hline Dun Carloway & 200 & 700 & Machair/pasture & IA & Overlain \\
\hline Aiginis mound 1 & 50 & 800 & Machair & IA & Overlain \\
\hline Aiginis mound 2 & 50 & 800 & Machair & IA & Overlain \\
\hline Chicken Head & $\mathrm{n} / \mathrm{a}$ & $\mathrm{n} / \mathrm{a}$ & Pasture & Unknown & Unknown \\
\hline Eye Peninsula & 600 & $\mathrm{n} / \mathrm{a}$ & Machair & Unknown & Unknown \\
\hline Gearreadh Scoir & $\mathrm{n} / \mathrm{a}$ & $\mathrm{n} / \mathrm{a}$ & Pasture & Unknown & Unknown \\
\hline
\end{tabular}

Table 2. Settlement sites on Lewis.

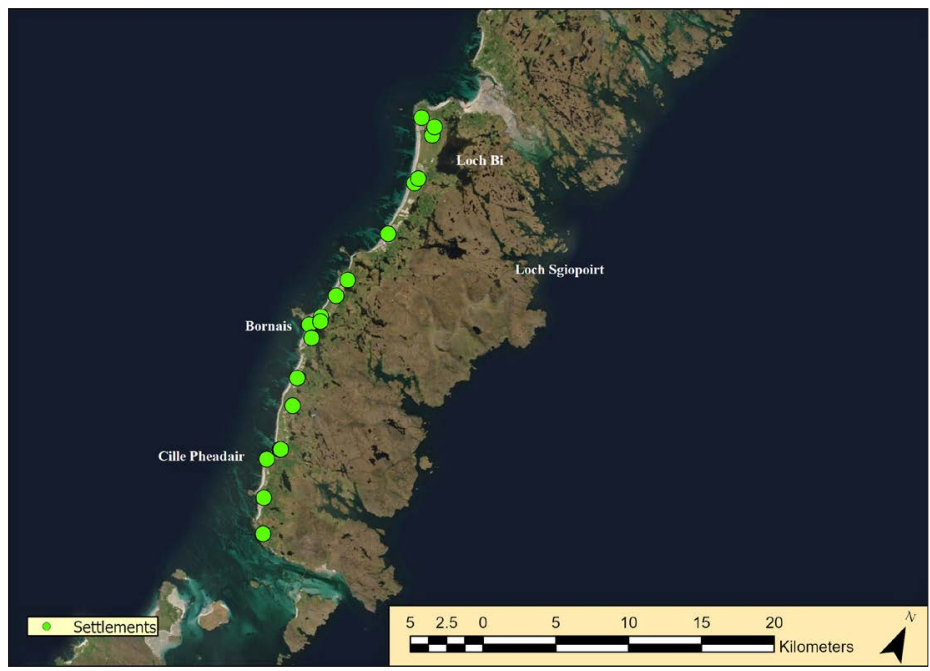

Figure 5. Norse

Settlement sites on

South Uist. 


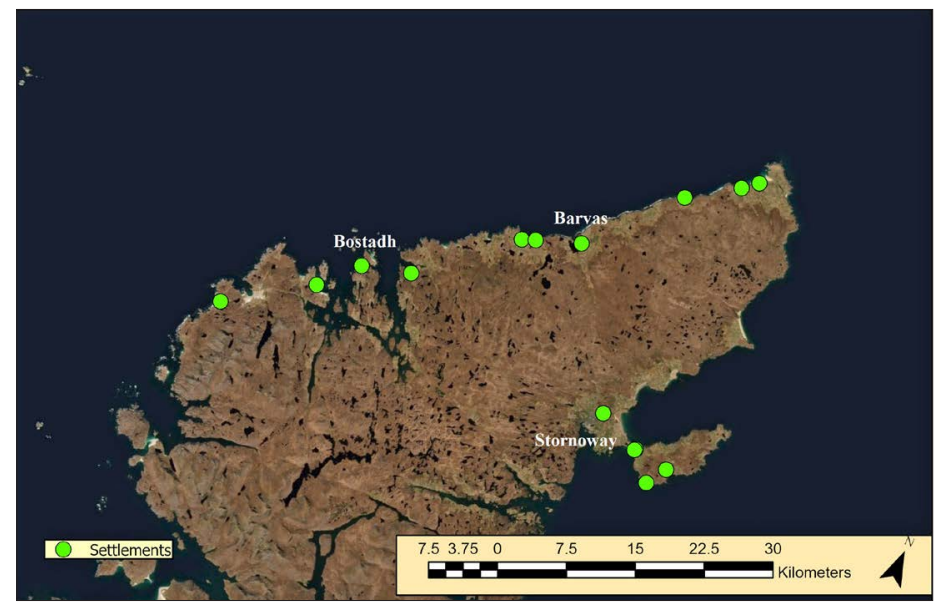

Figure 6. Norse settlement sites on Lewis

Nearly all settlement sites can be said to occur on the fertile calcareous (machair) arable land of the west coasts of South Uist and Lewis, and in the Stornoway/Eye peninsula area. Only one settlement was situated in a boggy/moorland area, north of Stornoway, at Gearreadh Scoir (Table 2). This discrepancy may be a reflection of survey and identification strategies in the Western Isles rather than a lack of Norse use of land outside the machair and could perhaps be explained by the relatively stable east coast, compared to the generally fragile landscapes of the lower-lying machair plains, of which the latter has been targeted for archaeological investigation, where a lot of anthropogenic material has been recovered as a result of coastal erosion, ploughing, rabbit damage, wind damage, etc. However, it is still likely that the machair area was the focus of Norse settlement as evidenced and documented by archaeological excavations at Bornais and Cille Pheadair, due to its agricultural potential (Sharples and Parker Pearson 1999; Sharples 2005; Parker Pearson 2012; Parker Pearson 2018; Sharples 2019; Sharples 2020).

While there is a general lack of precise datings, it can still be said that approximately half of all settlements on both Lewis and South Uist were placed in relation (imposed on, or within $500 \mathrm{~m}$ of) to Pictish period or earlier settlement sites (Tables 1\&2). There is one major difference between the settlement sites on South Uist and Lewis. South Uist only has three sites that are situated near natural, sheltered harbours, while all but one site on Lewis are located near or at such sites. This can be explained by differing topographies of the islands and will be explored further below.

\section{Discussion}

This section will place the Norse settlements in their landscape contexts, in terms of geographical features, namely freshwater lochs and maritime landscape features such as harbours and sailing routes. This section will also attempt to interpret the ethnic landscape through the Norse reuse of Pictish period and Iron Age settlement sites. 


\section{Geography and topography}

Freshwater lochs

The influence of freshwater lochs may be significant since they were already used as settlement site boundaries in the Scandinavian homelands (Lund 2008: 54). It has been argued that Scandinavian land division, which primarily took place during the Migration period (AD 400-600), was governed by such natural boundaries (Hovstad 1980). Sharples has argued that there is a lack of formal or above-ground markers to differentiate between infield and outfield on South Uist and that farm boundaries appear to have been marked differently on South Uist than in contemporary Norse Shetland or Norway (Sharples 2020: 425). Moreover, in comparison modern boundaries appear more territorial and often cross topographical zones (ibid: 420). Interestingly, both on Lewis and South Uist the settlement sites show an affinity towards freshwater lochs (Tables 1\&2). Many of the settlements on South Uist are closer to inland lochs than natural, sheltered harbours, such as Bornais mounds 1-3 (Fig. 7). This strengthens arguments that freshwater lochs, along with rivers and wetlands, were used as dividers between plots of land.

The placement of settlement sites near freshwater lochs is expected given the need for freshwater but would also have allowed easier storage and maintenance of Norse boats and ships during the winters (Sæbjørg Walaker Nordeide, personal communication 2019). What appears to be a Norse-period freshwater-loch harbour with nausts, linked to the sea by a

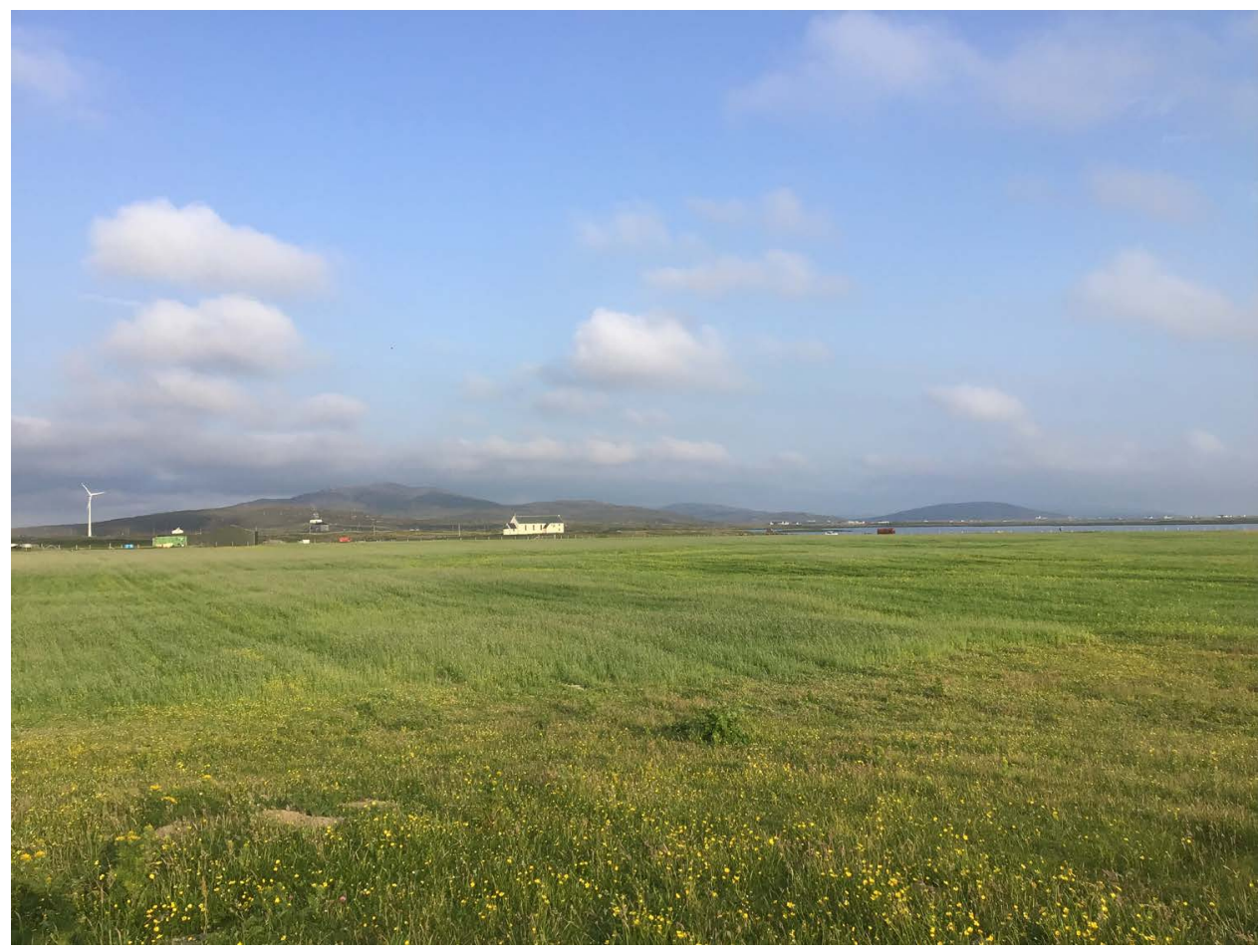

Figure 7. View from Bornais mound 3. Loch Aineort is c. $200 \mathrm{~m}$ to the southeast, visible in the photo. (C) The author. 
canal, is known from Skye (Martin and Martin 2017). Additionally, undated nausts are known from Pol a' Charra and Orasaigh, on South Uist (Niall Sharples 2020: 421), and elsewhere in the Western Isles.

\section{The place-name evidence}

According to Barbara Crawford the overall number of Norse origin settlement place names on Lewis and South Uist differ, with $86 \%$ of ON origin on Lewis (Crawford 1987: 96), and approximately $30 \%$ on South Uist. This could either be a result of more intense or earlier colonisation on Lewis, or of a stronger Gaelic influence on South Uist during and after the Late Norse period.

According to Peder Gammeltoft, Bólstaðr (ON habitation, farm, according to Norrön Ordbok), can also be a name for a cultivated area of land, which has been observed throughout the Hebrides, including on Lewis and South Uist (Gammeltoft 2001). The Bólstaðr names also suggest a period of secondary settlement and a movement away from the most important and fertile areas (ibid: 279). This indicates that the Norse settlements in the Hebrides developed similarly to those in Norway, both in terms of expansion and multigenerational occupation. The place name Bostadh is, as previously mentioned, derived from Bólstaðr and can, albeit with some uncertainty, be linked to a Pictish period site which was reused by the Norse. It could be argued that the importance of the site depended on its existence as an occupied Pictish settlement site when the Norse arrived in the region.

The place names also indicate Norse law and administration sites, or so called thing sites (Scandinavian assembly sites), on the Hebrides. One thing site has been identified in western Lewis, Cnoc an Tiongalaridh based on the place name and landscape-feature evidence (Sanmark 2017: 206). Moreover, the place name of Udal, (from ON oðal, land that cannot be changed), at an elite site on North Uist, has been argued to suggest the presence of an odalman ownership (Graham-Campbell and Batey 1998). Based on place names, no thing sites have been identified on South Uist, although Sharples argues for a possible one at Bornais (Sharples 2019).

\section{Ethnicity and Norse identity in the Norse world}

Judith Jesch advocates an overarching Norse identity in the wider Norse world, visible in a shared material culture and language in what she, and others, describe as a diaspora (2015). Zanette Tsigaridas Glørstad (2014: 169-70) has argued that the people of this Norse diaspora retained their own sense of identity, or Norseness, expressed in material culture, e.g. the construction of longhouses and the presence of Hiberno-Norse dress-pins throughout the Norse North Atlantic region. Anne-Sofie Gräslund has argued for a similar sense of Norseness among the settlers of Greenland (Gräslund 2010: 129). Julie Bond and Ruth Maher have suggested that new regional identities developed in response to different landscapes, resulting in different identities in e.g. Iceland and Orkney, although these people still retained an overarching Norse identity, based on shared religion and cosmology (Maher and Bond 2019). Migrant identities would have been important among the various diasporic communities of Norse-speaking peoples. It would be illuminating to see how the Norse viewed ethnicity, and themselves, in relation to the Pictish period population on the Western Isles. 
The question of who was migrating from Norway is important when considering settlement patterns, ethnicity and attitudes toward the past in a settlement landscape. Alan Macniven has highlighted that most of the migration to the Hebrides would have been conducted by elites from Norway (Macniven 2013: 11). Elite, or at least, 'middle' status landowners were the ones who could afford the journey from Scandinavia and still have the economic means to settle in a new landscape. Additionally, they would have been accompanied by people from the lower end of the social spectrum. John Raven has argued that the settlement landscape of South Uist would have suited odalmen, i.e. independent farmers who owned well defined land plots still visible in the clustering of Norse farm mounds (Raven 2005). Moreover, the presence of thing sites in the Hebrides, based on place names and topographic models, demonstrates that the Norse brought their own laws (Sanmark 2017). This strengthens the idea of an influx of landowners who had the power and means to impose a Norse-style system of administration.

\section{Reuse of earlier structures}

The data show that the Norse reused Pictish period settlement sites to a high extent (Tables 1\&2). This must have had a dimension that went beyond the simple reestablishment of an already existing farm or pilfering of building materials. The placement of Norse longhouses was a conscious choice that involved considerations of a practical, social, political and cosmological nature (Eriksen 2019: 110-1). In Scotland, the Norse reuse of sites has been argued to suggest either continuity or a reverence for the past (Leonard 2011; Harrison 2013), or discontinuity, imposition, or ideological destruction of the past (e.g. Crawford 1981).

The Iron Age broch at A' Bheirigh, on the Bhaltos peninsula of Lewis, which was occupied until the early $9^{\text {th }}$ century was not a site of Norse settlement, although Norse settled elsewhere on the coast of the same peninsula (Armit 1996). A' Bheirigh, as most Hebridean broch sites, is situated inland, c. $600 \mathrm{~m}$ from the nearest harbour at Tràigh na Beirigh. The remains of a nearby Norse settlement, however, were situated only $200 \mathrm{~m}$ from the coast. The only broch site in the corpus of data that produced a Norse find is Dun Carloway. Only one single sherd of Norse pottery was found, which has been interpreted as a sign of postNorse influence on the site (Lane 1983). The landscape context of Dun Carloway differs from A' Bheirigh, as Dun Carloway occupies a high point in the landscape overlooking a natural sheltered harbour. There is a possibility that the local place names, such as Carloway and Lagmann (Karl's Bay and Law man, the latter as a personal name included in the place name of a shieling site) (Cox 1987: 234) indicate elite activity, though the archaeological material is scarce.

The Norse likely chose to settle along the coast at natural, sheltered harbours, even if it would have been more convenient to occupy an already existing settlement site elsewhere. However, Pictish period settlement sites, such as Bostadh, with natural, sheltered harbours, along the coastal routes may have been settled first due to their strategic locations. Unfortunately, the dating of Bostadh is uncertain, which makes it and other unexcavated sites that appear to have been chosen because of their pivotal locations, impossible to interpret further. 
The Norse in Lewis and South Uist made use of the Pictish period material past, e.g. settlement mounds, to legitimise themselves in a new environment. Eva Thäte has argued that the Norse reuse of earlier settlement sites reflects a desire to create political stability (Thäte 2007). The physical, monumental nature of Pictish or other pre-Norse sites, such as Neolithic monuments in Orkney, seems to have been important for Norse settlers (Leonard 2011; Harrison 2013). Sharples and Parker Pearson have argued that Pictish period boundaries were retained by the Norse. On South Uist, this is visible in the Norse reuse and proximity to Pictish period settlement mounds (Sharples and Parker Pearson 1999; Parker Pearson 2012: 417). This practise is not visible in the Norse settlement of the Bhaltos peninsula of Lewis, where the location focus shifted, from the interior to the coast (Armit 1996: 202). It seems that Pictish period boundaries were used only if they fitted the settlement patterns favoured by the Norse.

\section{Topography, Harbours and Sailing}

Research relating to the relationship between Norse settlement sites, landing places and sea routes is well established. Examples can be found in studies of the maritime landscapes and Norse settlement sites in Shetland (Preston, Sanderson, Kinnaird et al. 2019: 154), and Orkney (Bates, Bates, Crawford et al. 2020: 15), among others. These all suggest that the Norse placed their settlements near natural, sheltered harbours. The Norse settlers, as their Pictish period predecessors, would have been reliant on the sea for sustenance, and landing places for their boats would have been a necessity. Certain harbours may have been of more strategic value than others, and it is likely that elite would have coveted pivotal locations in the seascape, e.g. Bornais, as argued by Sharples (2005). David Griffiths has suggested that this was also the case in the Irish Sea, where Norse elites would have claimed symbolic lordship through visual monuments such as already existing burial mounds at strategic points in the seascape (Griffiths 2004: 133).

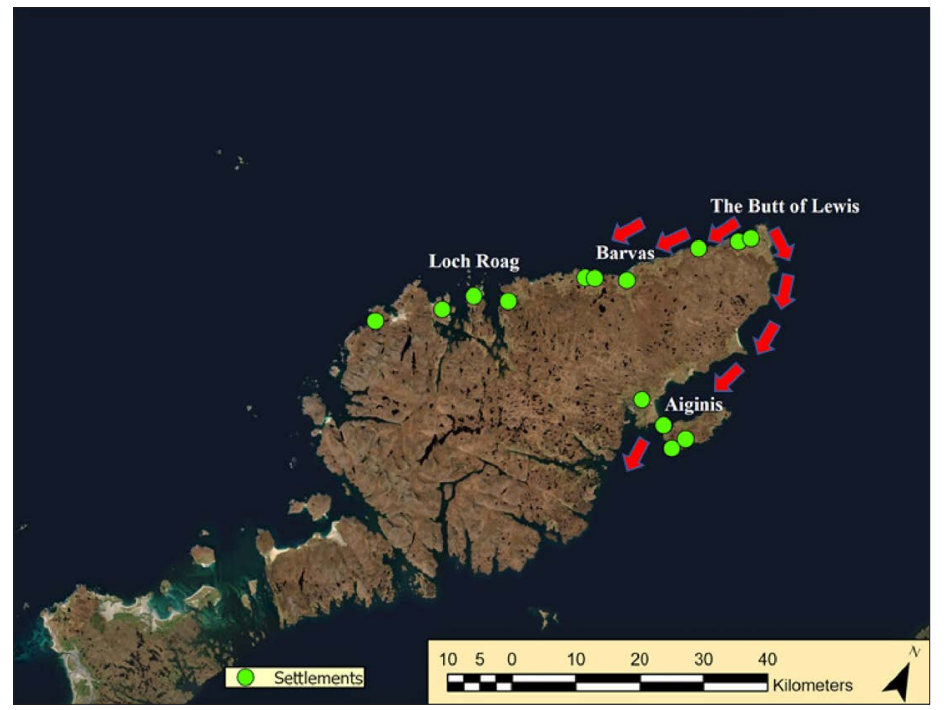

Figure 8. Norse settlements and sailing around Lewis. 


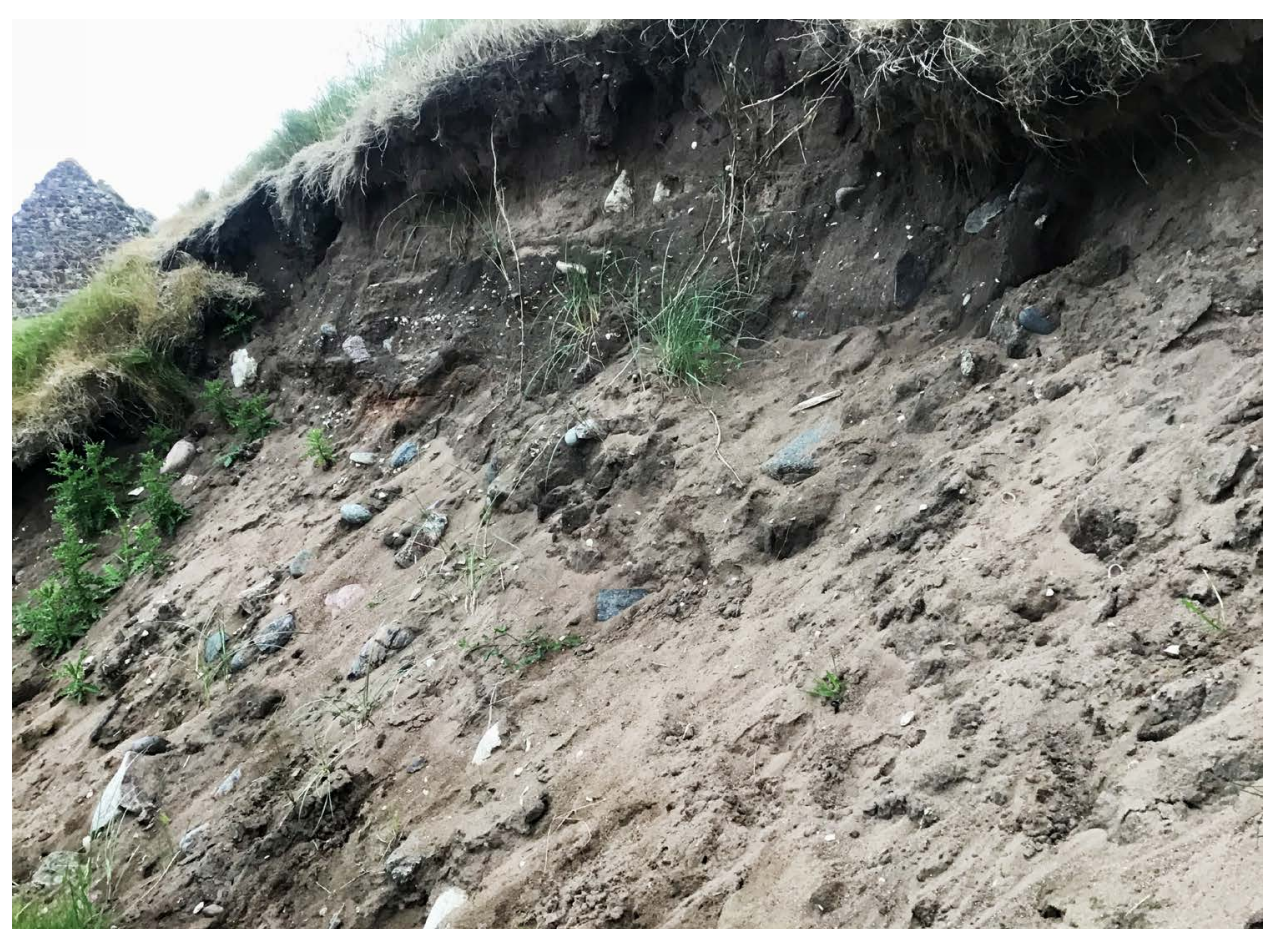

Figure 9. Aiginis mound 2. Multiperiod eroding settlement mound. View toward the southeast.

Photo: Joseph Thomas Ryder.

When sailing southwest from Cape Wrath (the north-western point of Sutherland and mainland Scotland) Lewis has the first safe harbours (Lawrence 2017). Figure 8 shows that Norse settlement sites cluster around natural, sheltered harbours, particularly at Loch Roag, Barvas and Stornoway. However, when sailing around Lewis, the northernmost point, the Butt of Lewis (Fig. 8), is the most perilous part, even considered to be more dangerous than Cape Wrath (ibid: 156), meaning that the harbours near Stornoway (Fig. 8) were the first obvious points of safe refuge for many vessels on their way further south. Their location along the Minch, the major sea-travel artery in north-western Scotland, was probably also a reason (ibid).

To the east of Stornoway, where a narrow isthmus connects the Eye peninsula to the rest of Lewis, lies Aiginis and its large, multi-period settlement mound, which is relevant for this article (Fig. 9). Due to coastal erosion this mound has produced both pottery and metalwork finds dating from the Viking and Late Norse periods (Lane 1983: 336). The place name Aiginis is derived from $\mathrm{ON}$ eið, meaning portage, and nes, meaning isthmus or headland (MacBain 1922: 90). The mound at Aiginis, though unexcavated, once again demonstrates how the Norse placed settlements at strategical and visible sites along the sea-routes on Lewis (Fig. 8).

Based on Norse elite pagan burials at harbours in the Inner Hebrides Barbara Crawford has also argued that initially the Norse settled near accessible landing places. Accordingly, 


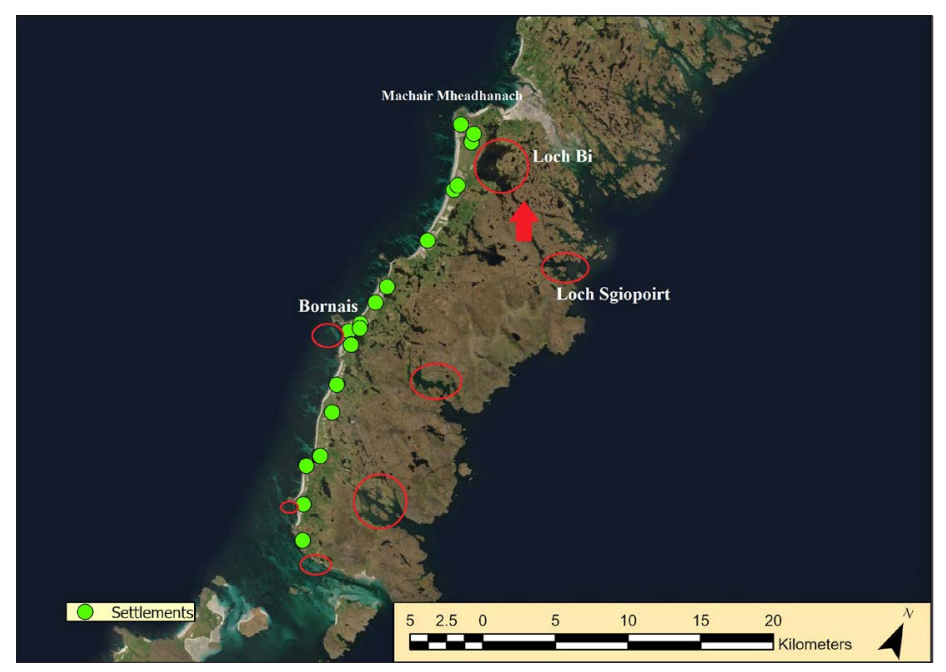

Figure 10. South Uist settlements and harbours. Harbours are circled.

settlements away from sheltered harbours, such as on the west coast of South Uist, would have been much later (Crawford 2018). $9^{\text {th }}$ century pagan Norse burials at Bhaltos (Macleod 1916) and Cnip (Dunwel, Cowie, Bruce et al. 1995) suggest a mid- to late $9^{\text {th }}$ century settlement of western Lewis. Place-name scholars have argued for a pre-Viking Age (AD 700800) Norse settlement on Lewis (Cox 1987). However, the lack of firm dates for Norse settlements and the fragmentary nature of excavated sites makes this argument problematic from an archaeological perspective.

Apart from Bornais 2, Dalabrog 1-2 and Smercleit, the settlement mounds of South Uist appear landlocked (Fig. 10), which is unusual for a maritime culture such as the Norse. However, the place-name evidence suggests several naval portages and routes on South Uist. One such system has been suggested in southern South Uist based on pre-modern, stone lined canals, but they cannot be accurately dated (Angus 2018).

The Norse must have recognised and taken advantage of isthmuses and portages around the isles, since such features were already used in Norway (e.g. Spangereid), where Norse vessels were constantly dragged across them. One portage route exists at Loch Sgiopoirt (ON: Ship fjord), from the north-east of South Uist to Loch Bì (McCullough 2000: 250) (Fig. 10). It is probably not a coincidence that the Machair Mheanach between Loch Bì and the Atlantic, has the highest concentration of Norse settlement mounds besides Bornais (Fig. 11). This cluster of undated Norse settlement mounds in the north west, was probably connected to this portage route (Fig. 10). It is possible that many of the settlement sites on South Uist were connected by a network of sea lochs, freshwater lochs, isthmuses, and manmade canals, which are still visible in the landscape but undated. The settlement sites of South Uist are generally closer to freshwater lochs than they are to the coast. This includes the elite site at Bornais, which lies $200 \mathrm{~m}$ from the nearest freshwater loch and $1.4 \mathrm{~km}$ from the nearest natural, sheltered harbour (Fig. 12). This, along with place-name evidence, suggests that the Norse mariners also used the inland waterscape. 


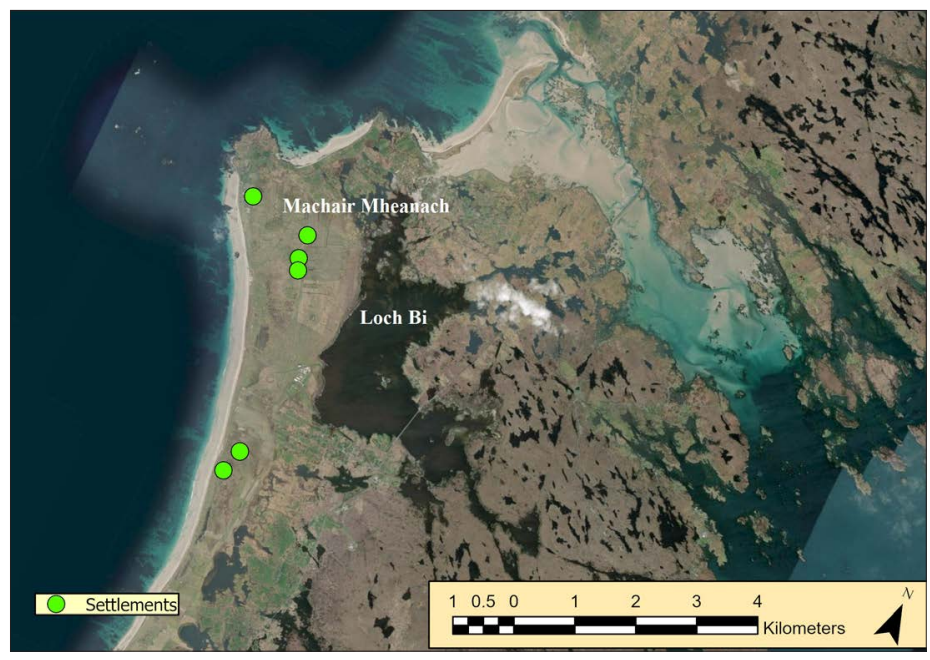

Figure 11. Norse settlement mounds at Machair Mheanach.

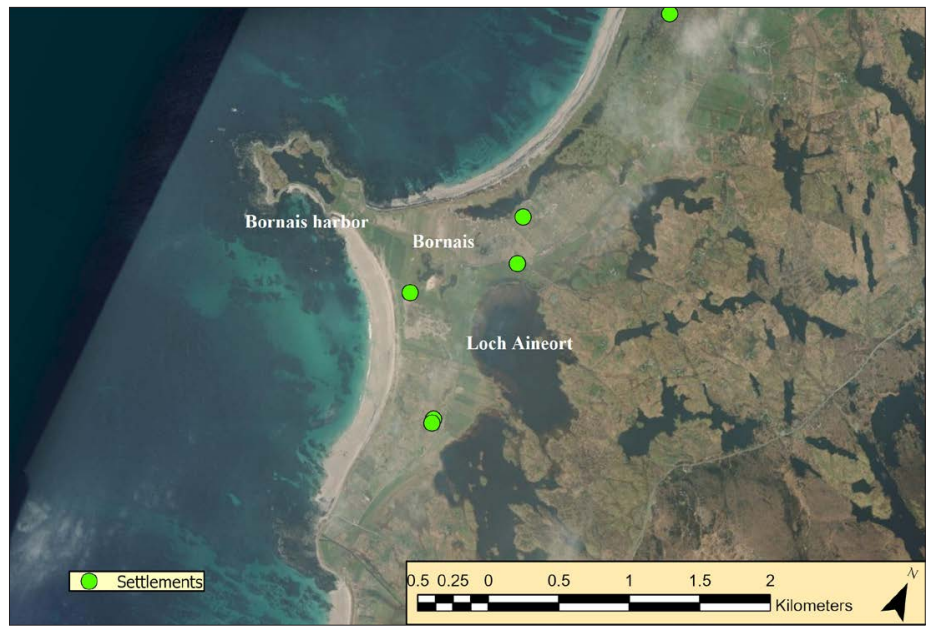

Figure 12. The

landscape of Bornais.

\section{Conclusions}

The Norse likely sought out key landscape features for their settlement sites around the North Atlantic, which corresponds to settlement models from western Norway. They imported their own laws, and at least for the first few generations, their pagan beliefs. The initial targets for settlement were probably already established Pictish period farmsteads in a settled landscape, although these would have had to conform to Norse landscape models. This was all done with little regard for pre-existing laws, customs and beliefs of the indigenous population. Pictish period land boundaries may have been kept to ease disputes between Norse settlers (Parker Pearson 2012). While site continuity existed in some places, it did not exist in others, suggesting that, as complex as reasons for reuse of settlement sites may be, the Norse primarily reused settlement sites that fit into their idea of the landscape. 
The landscape was settled and exploited in much the same way as in Scandinavia, with initial magnate farmsteads in pivotal locations and a secondary colonisation of lesser sites, such as indicated by the place name Bólstaðr. Since the archaeological record cannot provide any clear examples of settlement-site continuity from the late $8^{\text {th }}$ to $\mathrm{mid} / \mathrm{late} 9^{\text {th }}$ centuries, it is difficult to say that the Norse takeover was peaceful. There are, however, indications that the Norse did not replace the already existing Pictish period population on the islands entirely. Credible proof is visible in the continuation of pottery traditions (Lane 2012), and in the development of Hebridean longhouses (Sharples and Parker Pearson 1999). Although there must have been non-Norse peoples left in the area, the evidence suggests that the Norse were the dominant ethnic group who sought their own hegemony at the expense of the non-Norse natives.

So, the Norse treatment of the past through the reuse of Pictish period settlement sites suggests that they established a dominant identity through the reuse of structures that fit their own ideas of political legitimacy, as seen in Norse Orkney (Harrison 2013). Though the architectural style of the Hebridean longhouse may have been an expression of a Pictish period identity, as proposed by Sharples \& Parker Pearson (1999: 58), it is still a longhouse, both functionally and symbolically, and the longhouses were distinct expressions of the Norse diaspora identity. This suggests, at the very least, that the Pictish period elite must have been displaced (Graham-Campbell and Batey 1988; Armit 1996), although other evidence supports the idea that non-Norse potters were accepted on Norse farmsteads, as shown by the presence of Norse-era pottery, made with local technology but suited for a Norse diet (Lane 2012: 215). As a parallel, based on a similar presence of pottery on Bornholm, Magdalena Naum (2008: 258) has argued for the presence of lower status Slavic potters in the Scandinavian settlements on the island.

Norse migrants would have been attracted by the possibility of importing their own socio-political and religious systems into new homelands, where familiar established land boundaries were already in place. Both Lewis and South Uist would have offered a 'pull factor' for Norse migration, with available agricultural land, and a topography suited for a settlement pattern similar to Norway. The establishment of Norse settlements at strategic points in the maritime landscape, evidenced by Norse settlement mounds at isthmuses and natural, sheltered harbours, would also have been crucial to migrants attempting to gain power over a new homeland. The Norse would have asserted their ethnicity and legitimised themselves through the reuse of the past and the indigenous population does not seem to have been important. I argue that the survivors may even have been pressured to become Norse. There is a time gap of 15 to 250 years between activity at Pictish period settlement sites and the first detectable Norse activity in the western Scotland, which suggests that Pictish elite centres were abandoned and depopulated during the Norse raiding phase in the late $8^{\text {th }}$ to late $9^{\text {th }}$ centuries (Sharples 2019). Whether settlements of lesser status were also abandoned is difficult to say without further excavations at sites that include both Pictish period and Norse remains.

Although the material-culture evidence suggests that some Pictish period inhabitants remained, it should be stated that research, Crawford (1987: 74) and more recently, Sharples (2019), support ideas that the Norse culture was the dominant and that the non-Norse population survived as an underclass. 
While the Norse reuse of Pictish period settlement sites can either mean continuity or discontinuity, the act of establishing settlements on or near existing ones in a landscape already populated, must have had a different meaning to the Norse than the reuse of structures in their Scandinavian homelands. It has been argued that the construction of timber longhouses in treeless landscapes is non-functional and indicative of a need to express cultural identity (Eriksen 2019: 48). This supports ideas that the first longhouses in the Hebrides, built with turf and timber (at Bornais and Bostadh), signalled the establishment of a dominant Norse culture. It also suggests a hostile Norse takeover of the Western Isles, with an elite Norse culture superimposed on the Pictish period past. A past the Norse found useful for establishing their ethnicity, boundaries, and for displays of power among competing Norse elites. If the Pictish period population survived, it was probably as slaves or an underclass, forced to express their ethnicity through heterodox practices. Norse culture remained dominant, and probably developed a unique regionality, influenced by the Pictish period ethnicity that still remained.

\section{Acknowledgements}

I would like to express my gratitude to my supervisors, Ramona Harrison and Niall Sharples for their reviews and discussions. I would also like to thank Anne Irene Risøy, Eva Birgitta Andersson Strand, Daniela Hoffman, Anne Drageset, Søren Diinhoff, and Marte Mokkelbost, along with the two anonymous peer reviewers for comments and advice. I am also grateful the AHKR and the University of Bergen for supporting my project. I am thankful for the editors of this publication for their advice and acceptance of my article. Finally, I give my deepest gratitude to the late Norwegian Professor Sæbjørg Walaker Nordeide for her guidance and support.

\section{Data Availability Statement}

No original data were presented in this paper.

\section{Notes}

1 The chronology of Iron Age and medieval northern and western Scotland differs from the chronologies and terminologies often used in southern Scotland, Scandinavia, England and the European continent. The chronology used in this article is partly based on the chronology used in Ian Armit 1996 and on a general Scandinavian chronology: Pictish period AD 200-800. Viking Age or early Norse period, AD 800-1050. Late Norse period, AD 1050-1250.

2 The pre-Norse population of the Western Isles may have been more ethnically, politically, linguistically and religiously diverse than simply Pictish, as argued by Hunter 2004.

3 Norse is defined as someone who speaks the Old Norse language and practices a culture that originated or is derived from Scandinavia. 


\section{Bibliography}

Angus, Stewart

2018 The aquatic context of Caisteal Ormacleit, South Uist, Outer Hebrides. Proceedings of the Society of Antiquaries of Scotland 147: 243-59.

Armit, Ian

1996 The Archaeology of Skye and the Western Isles. Edinburgh University Press, Edinburgh.

Barrett, James H

2003 Culture contact in Viking Age Scotland, In Contact, Continuity and Collapse: The Norse colonization of the North Atlantic, Studies in the Early Middle Ages, edited by J. H. Barrett, pp. 73-111. Brepols, Turnhout.

2015 Maritime societies and the transformation of the Viking Age and Medieval world. In Maritime societies of the Viking and Medieval world, edited by J. H. Barrett, and S. J. Gibbon, pp. 1-13. Maney, Leeds.

Bates, Richard C, Martin R. Bates, Barbara Crawford, Alexandra Sanmark and John Whittaker

2020 The Norse Waterways of West Mainland Orkney, Scotland. Journal of Wetland Archaeology, 1-18.

Bertelsen, Reidar

1973 Gårdshaugene i Harstad kommune. Et bidrag til områdets økonomiske historie i middelalderen. Unpublished Master's thesis. University of Bergen, Bergen.

Church, Michael

2002 Plants and people in the later prehistoric and Norse periods of the Western Isles of Scotland. Unpublished PhD thesis. University of Edinburgh, Edinburgh.

Cowie, T. and Mary Macleod Rivett

2015 Machair Bharabhais: a landscape through time. Journal of the North Atlantic (special volume) 9: 99-107.

Cox, Richard

1987 Place-names of the Carloway Registry, Isle of Lewis. Unpublished PhD thesis. University of Glasgow, Glasgow.

Crawford, Barbara

1987 Scandinavian Scotland. Leicester University Press, Leicester.

2018 Politics and power in the Western isles c. AD 1000-1300: the documentary evidence. In Cille Pheadair: A Norse farmstead and Pictish burial cairn in South Uist, edited by M. Parker Pearson, pp. 580-7. Oxbow, Oxford.

Crawford, Ian

1981 War or peace - Viking colonization in the Northern and Western Isles of Scotland reviewed. In Proceedings of the Eighth Viking Congress, Arhus, 24-31 August 1977, edited by H. BekkerNielsen, Peter Foote and O. Olsen, pp. 259-69. Odense University Press, Odense.

Croix, Sarah

2014 Houses and Households in Viking Age Scandinavia - Some case Studies. In Dwellings Identities and Homes. European Housing Culture from the Viking Age to the Renaissance, Jutland Archaeological Society Publications Vol. 84, edited by I. M. S. Kristiansen and K. Giles, pp. 113-26. Aarhus University Press, Aarhus.

Dommasnes, Liv Helga and Alf Tore Hommedal

2016 One thousand years of tradition and change on two West-Norwegian farms AD 200-1200. In The farm as a social arena, edited by L. H. Dommasnes, D. Gutsmiedl-Schümann and A. T. Hommedal, 127-70. Waxmann, Münster.

Dunwell, A. J., T. G. Cowie, M. F. Bruce, T. Neighbour and A. R. Rees

1995 A Viking Age cemetery at Cnip, Uig, Isle of Lewis, Proceedings of the Society for Antiquaries of Scotland 125: 719-52. 
Eriksen, Marianne Hem

2019 Architecture, Society, and Ritual in Viking Age Scandinavia. Doors, Dwellings, and Domestic Space. Cambridge University Press, Cambridge.

Gilbert E, Seamus O’Reilly, Michael Merrigan, Darren McGettigan, Veronique Vitart, Peter K. Joshi, David W. Clark, Harry Campbell, Caroline Hayward, Susan M. Ring, Jean Golding, Stephanie Goodfellow, Pau

Navarro, Shona M. Kerr and Carmen Amador

2019 The genetic landscape of Scotland and the Isles. Proceedings of the National Academy of Sciences 116 (38): $1-7$.

Gammeltoft, Peder

2001 The place-name element Bólstaðr in the North Atlantic area. C. A. Reitzels Forlag A/S, Copenhagen.

Gansum, Terje

1995 Jernaldergravskikk i Slagendalen - Oseberghaugen og storhaugene i Vestfold - lokale eller regionale symboler. Unpublished Master's thesis- University of Oslo, Oslo.

Glørstad, Zanette

2014 Homeland-Strange land-New land. Material and theoretical aspects of defining Norse identity in the Viking Age. In Celtic-Norse Relationships in the Irish Sea in the Middle Ages 800-1200, edited by J. V. Sigurðsson, and T. Bolton, pp. 151-70. Brill, Leiden and Boston.

Goodacre, Sara, Agnar Helgason, J. Nicholson, L. Southam, L Ferguson, E. Hickey, E. Vega, K. Stefánsson, R. Ward, and B. Sykes

2005 Genetic evidence for a family-based Scandinavian settlement of Shetland and Orkney during the Viking periods. Heredity 95: 129-35.

Graham-Campbell, James and Colleen E. Batey

1998 Vikings in Scotland - An Archaeological Survey. Edinburgh University Press, Edinburgh.

Griffiths, David

2004 Settlement and Acculturation in the Irish Sea Region. In Land Sea and Home, edited by J. Hines, A. Lane, and M. Redknap, pp. 125-38. Routledge, London.

2015 Status and identity in Norse settlements: a case study from Orkney. In Maritime societies of the Viking and Medieval world, edited by J. H. Barrett and S. J. Gibbon, p. 232. Maney, Leeds.

Griffiths, David and Jane Harrison

2011 Interpreting Power and Status in the Landscape of Viking Age Orkney. In Viking Settlements and Society, Proceedings of the XVI Viking Congress, Reykjavik, 2009, edited by S. Sigmundsson, pp. 132-46. National Museum of Iceland, Reykjavik.

Gräslund, Anne-Sofie

2010 How Did the Norsemen in Greenland See Themselves? Some Reflections on 'Viking Identity' Norse Greenland: Selected Papers from the Hvalsey Conference 2008. Journal of the North Atlantic 2 (1): 131-7.

Gjerpe, Lars Erik

2016 Iron Age building traditions in Eastern Norway: regions and landscapes. In The Agrarian Life of the North 2000 BC-AD 1000. Studies in rural farming and settlement in Norway, edited by Frode Iversen and H. Petersson, pp. 202-20. Portal Books, Kristiansand.

Hovstad, Håkon

1980 Gårdsgrenser. Et bosetningshistorisk hjelpemiddel? Institutt for sammenlignende kulturforskning, serie B, skrifter LXII. Universitetsforlaget, Oslo.

Iversen, Frode

2008 Eiendom, makt og statsdannelse. Kongsgårder og gods $i$ Hordaland i yngre jernalder og middelalder. UBAS nordisk 6, Bergen.

Jennings, Andrew and Arne Kruse

2005 An ethnic enigma: Norse, Pict, and Gael. In Viking and Norse North Atlantic, Selected Papers from the Proceedings of the Fourteenth Viking Congress, Tórshavn, the Faroe Islands, edited by A. Mortensen and S. V. Arge, pp. 251-63. Føroya Fróðskaparfelag, Tórshavn. 
Jesch, Judith

2015 The Viking Diaspora. Routledge, New York.

Harrison, Jane

2013 Settlement Landscapes in the North Atlantic: The Northern Isles in context, ca. 800-1150 AD.

Journal of the North Atlantic 4 (1): 129-47.

Hunter, John

2004 Saints and sinners: the archaeology of the Late Iron Age in the Western Isles. In In the Shadow of the Brochs: The Iron Age of Scotland, edited by B. Ballin Smith and I. Banks, pp. 129-38.

Tempus, Charleston.

Lane, Alan

1983 Dark-Age and Viking-Age pottery in the Hebrides, with special reference to the Udal, North Uist. Unpublished PhD thesis. University of London, London.

2010 A Viking-age and Norse pottery in the Hebrides. In The Viking Age: Ireland and the West, edited by B. Ballin Smith and I. Banks, pp. 204-16. Four Courts, Dublin.

Lawrence, Martin

2017 Outer Hebrides Clyde Cruising Club sailing directions and anchorages. Imray, Laurie, Norie \& Wilson Ltd, St Ives.

Leonard, Allison

2011 Vikings in the Prehistoric Landscape: Studies on Mainland Orkney. Landscapes 12 (1): 42-68.

MacBain, Alex

1922 Place-Names. Highlands \& Islands of Scotland. Eneas MacKay, Stirling.

Macleod Rivett, Mary

2016 Gall or Ghaedheil: $13^{\text {th }}$ century identities in the Western Isles. In Shetland and the Viking World: papers from the Proceedings of the Seventeeth Viking Congress Lerwick, edited by V. Turner, O.

Owen and D. Waugh, pp. 153-7. Shetland Heritage Publications, Lerwick.

Macniven, Alan

2013 Modelling Viking Migration to the Inner Hebrides. Journal of the North Atlantic 4: 3-18.

Maher, Ruth and Julie Bond

2019 The Making Of Social Landscapes - Identity and Monumentality in the North Atlantic Isles. In Archaeology of Identity and Dissonance, Context for a brave new world, edited by D. George and B. Kurchin. University Press of Florida, Gainesville.

Margaryan, Ashot, J. Daniel Lawson, Martin Sikora, Fernando Racimo, Simon Rasmussen, Ida Moltke,

Lara M. Cassidy, Emil Jørsboe, Mikkel W. Pedersen, Thorfinn Korneliussen, Helene

Wilhelmson, Magdalena M. Buś, Peter de Barros Damgaard, Rui Martiniano, Gabriel Renaud, Claude

Bhérer, J. Víctor Moreno-Mayar, Anna K. Fotakis, Marie Allen, Raili Allmäe, Martyna Molak, Enrico

Cappellini, Gabriele Scorrano, Hugh McColl, Alexandra Buzhilova, Allison Fox, Anders Albrechtsen, Berit

Schütz, Birgitte Skar, Caroline Arcini Ceri Falys, Charlotte Hedenstierna-Jonson, Dariusz Błaszczyk, Denis

Pezhemsky, Gordon Turner-Walker, Hildur Gestsdóttir, Inge Lundstrøm, Ingrid Gustin, Ingrid

Mainland, Inna Potekhina, Italo M. Muntoni, Jade Cheng, Jesper Stenderup, Jilong Ma, Julie Gibson, Jüri

Peets, Jörgen Gustafsson, Katrine H. Iversen, Linzi Simpson, Lisa Strand, Louise Loe, Maeve

Sikora, Marek Florek, Maria Vretemark, Mark Redknap, Monika Bajka, Tamara Pushkina, Morten

Søvsø, Natalia Grigoreva, Tom Christensen, Ole Kastholm, Otto Uldum, Pasquale Favia, Per Holck, Sabine

Sten, Símun V. Arge, Sturla Ellingvåg, Vayacheslav Moiseyev, Wiesław Bogdanowicz, Yvonne

Magnusson, Ludovic Orlando, Peter Pentz, Mads Dengsø Jessen, Anne Pedersen, Mark Collard, Daniel G.

Bradley, Marie Louise Jørkov, Jette Arneborg, Niels Lynnerup, Neil Price, M. Thomas, P Gilbert, Morten E.

Allentoft, Jan Bill, Søren M. Sindbæk, Lotte Hedeager, Kristian Kristiansen, Rasmus Nielsen, Thomas

Werge and Eske Willerslev

2020 Population genomics of the Viking world. Nature 585: 390-6. 
Martens, Vanstrup Vibeke

2016 North Norwegian Farm Mounds - economic resources and landscape conditions. In Ruralia 10. Agrarian technology in the medieval landscape, edited by J. Klapste, pp. 173-83. Brepols, Turnhout.

Martin, Colin and Paula Martin

2017 Rubh' an Dùnain: a multi-period maritime landscape on the Isle of Skye, Inner Hebrides, Scotland. International Journal of Nautical Archaeology 47 (1): 140-58.

2000 Investigating Portages in the Norse Maritime Landscape of Scotland and the Isles. Unpublished $\mathrm{PhD}$ thesis. University of Glasgow, Glasgow.

Naum, Magdalena

2008 Homelands Lost and Gained: Slavic Migration and Settlement on Bornholm in the Early Middle Ages. Lund Studies in Historical Archaeology 9. Lund University, Lund.

Neighbour, Tim and Chris Burgess

1997 Traigh Bostadh (Uig parish). Discovery and Excavation in Scotland 1996: 113-4.

Lund, Julie

2008 Banks, Borders and Bodies of Water in a Viking Age Mentality. Journal of Wetland Archaeology 8: 53-72.

Parker Pearson, Mike

2012 From Machair to Mountains: Archaeological Survey and Excavation in South Uist. Oxbow, Oxford.

2018 Cille Pheadair: A Norse farmstead and Pictish burial cairn in South Uist. 10th ed. Oxbow, Oxford.

Preston, John, David Sanderson, Timothy Kinnaird, Anthony Newton, Marianne Nitter, Joris Coolen,

Natascha Mehler and Andrew Dugmore

2019 Dynamic beach response to changing storminess of Unst, Shetland: implications for landing places exploited by Norse communities. The Journal of Island and Coastal Archaeology 15 (2): $1-26$.

Raven, John

2005 Medieval Landscapes and Lordship in South Uist. Unpublished PhD thesis, University of Glasgow, Glasgow.

Rennell, Rebecca

2015 Re-engaging with the Iron Age landscapes of the Outer Hebrides. Journal of the North Atlantic 9(sp9): 16-34.

Ritchie, Anna

1993 Viking Scotland. B. T. Batsford/Historic Scotland, London.

Sanmark, Alexandra

2017 Viking Law and Order. Places and Ritual of Assembly in the Medieval North. Edinburgh University Press, Edinburgh.

Sauvage, Raymond and Marte Mokkelbost

2016 Rural buildings from the Viking and early Medieval period in Central Norway. In The Agrarian Life of the North 2000 BC-AD 1000. Studies in rural farming and settlement in Norway, edited by F. Iversen and H. Petersson, pp. 275-92. Portal Books, Kristiansand.

Sharples, Niall and Mike Parker Pearson

1999 Norse Settlement in the Outer Hebrides, Norwegian Archaeological Review. 32: 1: 41-62.

Sharples, Niall, Claire Ingrem, Peter Mulville, Jacqui Powell, Adrienne Powell, and Kelly Reed

2015 The Viking occupation of the Hebrides: evidence from the excavations at Bornais, South Uist. In Maritime Societies of the Viking and Medieval World Society for Medieval Archaeology Monograph 37, edited by J. Barrett and S. J. Gibbon, pp. 237-58. Maney Publishing, Leeds.

Sharples, Niall

2005 A Norse farmstead in the Outer Hebrides: excavations at Mound 3, Bornais, South Uist. Oxbow Books, Oxford. 
2019 A Norse settlement in the Outer Hebrides. Oxbow Books, Oxford.

2020 The economy of a Norse settlement in the Outer Hebrides: excavations at mounds 2 and $2 \mathrm{~A}$ Bornais, South Uist. Oxbow Books, Oxford.

Skre, Dagfinn

1998 Herredømmet bosetning og besittelse på Romerike 200-1350 e. Kr. Acta humaniora 32.

Small, Alan

1969 The distribution of Settlement of Shetland and Faroe in Viking Times. Saga-Book of the Viking Society 17: 145-55.

Smith, Brian

2001 The Picts and the Martyrs or Did Vikings Kill the Native Population of Orkney and Shetland? Northern Studies 36: 7-36.

Zachrisson, Torunn

1995 The Odal and its manifestations in the Landscape. Current Swedish Archaeology 2: 219-38.

Øye, Ingvild

2009 Settlement patterns and field systems in medieval Norway. Landscape History 30 (2): 37-54. 